\title{
Sales Representatives, Services
}

National Cancer Institute

\section{Source}

National Cancer Institute. Sales Representatives, Services. NCI Thesaurus. Code C122505.

Advertising sales agents sell or solicit advertising, including graphic art, advertising space in publications, custom made signs, or TV and radio advertising time. They may obtain leases for outdoor advertising sites or persuade retailer to use sales promotion display items. Insurance sales agents sell life, property, casualty, health, automotive, or other types of insurance. They may refer clients to independent brokers, work as an independent broker, or be employed by an insurance company. Travel agents plan and sell transportation and accommodations for travel agency customers. They help determine destination, modes of transportation, travel dates, costs, and accommodations required. 